Vol. 1 No. 2 Agustus 2021, e-ISSN : 2797-0140 | p-ISSN : 2797-0590

\title{
PENERAPAN PEMBELAJARAN DARING TERHADAP HASIL BELAJAR DAN KREATIVITAS PESERTA PELATIHAN KEPEMIMPINAN PENGAWAS MASA PANDEMI COVID 19
}

\author{
MASTINAH \\ Widyaiswara BKPSDMD Prov.Kep. Bangka Belitung \\ Email : mastinah659@gmail.com
}

\begin{abstract}
ABSTRAK
Penelitian ini menggunakan penelitian kuantitatif dan pendekatan analisa deskriptif untuk memberikan informasi data yang diamati agar bermakna dan komunikatif. Bedasarkan hasil analisis data kuantitatif dari pembelajaran pada Pelatihan kepemimpinan Pengawas yang dselenggarakan oleh Badan Kepegawaian dan Pengembangan Sumber daya Manusia Daerah Kabupaten Bangka Barat bekerja sama dengan Badan Kepegawaian dan Pengembangan Sumber daya Manusia Daerah Provinsi Kepulauan Bangka Belitung. Pelaksanaan pembelajaran daring Distence Learning dan e learning dengan bimbingan Host/PIC dan Widyaiswara. Peserta melaksanakan pembelajaran daring dan berinteraksi dengan Widyaiswara menggunakan beberapa aplikasi seperti Google Classroom, Zoom, Google Meet dan Whatsapp Group. Tujuan penelitian untuk mengetahui pengaruh pembelajaran daring terhadap hasil belajar dan kreativitas peserta pada masa COVID-19. Responden berjumlah 40 peserta dari pejabat pengawas Kabuapten Bangka Barat. Hasil penelitian menunjukkan bahwa pembelajaran daring pada masa pandemi COVID-19 berpengaruh signifikan terhadap hasil belajar dan kreativitas Peserta, Pengaruh tersebut dikarenakan terganggunya signal, sehingga ada beberapa yang telat absen dalam sistem, sestem error dan terlihat adanya peserta yang mengantuk. Selain itu terdapat beberapa peserta yang tidak terekam nama /email, namanya lebih dari satu kali, pada saat pre test dan post test. Dan hasil paparan tugas diskusi kelompok terdapat beragam metode yang dihasilkan peserta dan hanya satu kelompok yang menerapkan contoh. Peserta bebas untuk mengembangkan kreativitasnya untuk mengadopsi materi dan sumber lainnya. Namun pembahasan hasil diskusi kurang maksimal karena terbatasnya waktu. Sehingga diskusi kurang maksimal. Kesimpulan dari penelitian ini pembelajaran daring perlu dukungan sarana dan prasarana yang memadai, agar pembelajaran dapat lebih efektif.
\end{abstract}

Kata kunci: Pembelajaran daring, Hasil belajar, Kreativitas, Era Pandemi Covid 19

\section{PENDAHULUAN}

Kreativitas dapat didefinisikan sebagai kemampuan seseorang untuk menciptakan sesuatu yang baru baik berupa gagasan maupun karya nyata. Karya tersebut relatif berbeda dengan apa yang telah ada sebelumnya. Antara lain yaitu berkenaan dengan bidang ilmu pengetahuan, sastra, atau seni lainnya. Untuk menghasilkan kreativitas diperlukan gairah kreatif yang berakar pada rasa keingintahuan dan keterbukaan alamiah serta komitmen yang besar untuk mewujudkan gagasan kreatifnya.

Adanya Pandemi virus COVID-19 ini membuat proses pembelajaran menjadi berubah dari yang tatap muka menjadi pembelajaran jarak jauh, distance Learning, e- Learning, Daring (dalam Jaringan) dan Luring (tatap Muka). Dampak Pandemi covid 19 ini terus berlangsung dan meningkat sampai saat ini dan sehingga mempengaruhi penyelenggaraan pendidikan dan pelatihan diwilayah Prov.Kep. Bangka Belitung. Sesuai dengan Surat Edaran LAN No.2/K.1/HKM.02.3/2021 tentang pedoman penyelenggaraan diklat PKP. Maka BKPSDMD Kabuapten Barat sebagai yang pertama menyelenggarakan PKP turut serta mengacu pada aturan LAN tersebut. Dan melaksanakan dengan metode Blended Learning, dengan e-learning dan klasikal yang hanya akan dilaksanakan pada saat seminar evaluasi rancangan aksi perubahan dan Seminar evaluasi Laporan Aksi Perubahan. Pelaksanaan tersebut tentu saja dengan melakukan penerapan protokol kesehatan covid yang baik agar tetap terjaga kesehatan semua orang dan terhindar dari penularan virus civid 19. Hal ini juga diungkapkan oleh Nur 
Fitria dalam penelitiannya. Dan Sejalan dengan hasil penelitian tersebut Nur Fitriya, menyatakan bahwa kepatuhan dan ketaatan kepada Allah, keihklasan, kesabaran dan ketabahan menghadapi pandemi covid-19 bersinergi dengan kesadaran kolektif berbasis keluarga untuk tetap sehat, yaitu mencuci tangan dengan air dan sabun yang mengalir, memakai masker ketika ke luar rumah, menjaga jarak, menjaga pola makan dan berolahraga untuk menjaga imun supaya tetap sehat.

Pelatihan Kepemimpinan Pengawas Kabupaten Bangka Barat merupakan hal yang sangat penting dalam pengembangan kompetensi pejabat pengawas yang dapat mempengaruhi kualitas Pelayanan Publik saat ini, dan di masa yang akan datang. Pada kesempatan ini penulis hendak mengetahui bangimana pengaruh pembelajaran daring ini pada penerapan salah satu materi pembelajaran dengan indikator hasil belajar dari Agenda II Kepemimpinan pelayanan mata pelatihan Berpikir Kreatif dalam penekanan pada kemampuan berpikir kreatif untuk mengasilkan rancangan strategi inovasi pelayanan publik pada unit kerja organisasi di Instansi peserta.

Pembelajaran daring melalui pembelajaran Mata Pelatihan sub bagian dari Berpikir Kreatif dalam Pelayanan pada Agenda II Kepemimpinan Pelayanan. Yang terdiri dari konsep, Teknik- teknik dan inovasi, praktik serta strategi berpikir kreatif dan inovasi dalam pelayanan publik sesuai dengan tugas dan fungsi jabatannya. Terdapat 9 model Teknik berpikir kreatif yang dapat dipraktekkan oleh peserta pelatihan untuk menghasilkan ide-ide kreatif dalam berinovasi. Selanjutnya tujuan dari pembelajaran ini adalah untuk menstimulus peserta pelatihan agar dapat mengembangkan kreativitasnya dalam melahirkan ide atau gagasan kreatif untuk memecahkan masalah unit kerja bidang tugasnya dengan merancang dan mengimplementasi Aksi perubahan di unit kerja organisasinya.

Menurut Horrace (dalam Sumarno, 2003) kreativitas adalah kemampuan seseorang untuk menemukan cara-cara baru bagi pemecahan problema-problema, baik yang berkenaan dengan ilmu pengetahuan, seni sastra atau seni lainnya, yang mengandung suatu hasil atau pendekatan yang sama sekali baru bagi yang bersangkutan, meskipun bagi orang lain merupakan suatu hal yang tidak asing lagi. Torrance \& Rockenstein, (1988) mendefinisikan kreativitas sebagai proses menjadi sensitif sehingga melakukan pencarian solusi untuk menyelesaikan masalah. Kreatifitas Menurut Munandar (2012: 31), kreativitas atau berfikir kreatif merupakan kemampuan untuk melihat berbagai kemungkinan penyelesaian suatu masalah. Juga merupakan bentuk pemikiran yang sampai saat ini masih kurang mendapat perhatian. Seperti penerimaan pengetahuan, ingatan, dan penalaran (berfikir logis).

Santrock (2007) mengungkapkan ada enam faktor yang dapat mempengaruhi kreatifitas, diantaranya yaitu: 1). Jenis Kelamin Anak laki-laki menunjukkan kreativitas yang lebih besar dari anak perempuan, terutama setelah berlalunya masa kanak-kanak. Untuk sebagian besar hal ini disebabkan oleh perbedaan perlakuan terhadap anak laki-laki dan anak perempuan. Anak laki-laki lebih diberi kesempatan untuk mandiri, didesak oleh teman sebayanya untuk lebih mengambil resiko, dan didorong oleh para orang tua dan guru untuk lebih menunjukkan inisiatif dan orisinalitas. Santrock (2002:327) kreativitas adalah kemampuan untuk memikirkan sesuatu dengan cara-cara yang baru dan melahirkan suatu solusi yang unik terhadap masalah-masalah.

Di dalam teori investasi, tingkatan kreativitas memerlukan sumber daya setiap orang yang melibatkan enam sumber daya yang berbeda tetapi saling terkait, yaitu: kemampuan intelektual, pengetahuan, pola berpikir, kepribadian, motivasi, dan lingkungan (Sternberg 2003:107)

Supriyadi (1994: 6) mengemukakan bahwa "creativity is a matter of definition". Pendapat tersebut dimaknai bahwa tidak satu definisipun yang dianggap mampu mewakili pemahaman yang beragam tentang kreativitas. Maka dengan ini penulis tertarik untuk melakukan penelitian yang berjudul pengaruh Pembelajaran Daring Pada Peserta Pelatihan Kepemimpinan Pengawas Era Pandemi Covid 19. (LAN RI,2019), Untuk menstimulus Kreativitas peserta pelatihan dalam melakukan Inovasi pelayanan Publik, perlu didukung 
dengan sarana dan prasarana yang memadai dan lengkap bagi peserta juga panitia, dan narasumber/fasilitator agar inovasi dapat terwujud. Peserta perlu dorongan atau gairah yang membangkitkan imanjinasinya antara lain Gairah kreatif menurut Golden (2007:19) merupakan sebuah keinginan yang kuat dan mendorong untuk melibatkan dirinya dalam sebuah upaya kreatif seperti membuat aplikasi, membuat SOP, melakukan pembinaan atau menggali dan memecahkan permasalahan yang dihadapi secara efektif dan efisien.

Kreativitas dapat didefinisikan sebagai kemampuan seseorang untuk menciptakan sesuatu yang baru baik berupa gagasan maupun karya nyata dan relatif berbeda dengan apa yang telah ada sebelumnya baik berkenaan dengan bidang ilmu pengetahuan, sastra, atau seni lainnya. Untuk menghasilkan kreativitas diperlukan gairah kreatif yang berakar pada rasa keingintahuan dan keterbukaan alamiah serta komitmen yang besar untuk mewujudkan gagasan kreatifnya.

Harapan hasil belajar dari PKP agar peserta dapat menghasilkan Inovasi berupa Rancangan Aksi Perubahan. Rancangan ini akan diimplementasikan pada saat off campus di kantor/ tempat kerja masing-masing. Berpikir kreatif sebagai kreativitas peserta dalam memikirkan suatu solusi pemecahan masalah sebagai pedoman membuat Rencana Aksi dalam tugas di instansinya. Bangaimana penerapan kreativitas peserta PKP untuk mengasilkan rancangan aksi perubahan, maka peneliti tertarik untuk meneliti bagaimanakah pengaruh pembelajaran daring terhadap kreativitas peserta pada Pelatihan Kepemimpinan Pengawas era Pandemi covid 19 di Kabupaten Bangka Barat.

\section{METODE PENELITIAN}

Penelitian ini menggunakan metode penelitian kuantitatif dengan pendekatan analisa deskriftif dimana peneliti melakukan analisis data bersifat kuantitatif /statistik dan membandingkan terhadap hasil penelitian yang dilakukan peneliti lain. Pengamatan dan survey kegiatan tertentu yang berpengaruh pada saat pembelajaran. Jumlah sample 39 peserta PKP di Kabupaten Bangka Barat. Hasil penelitian menunjukan terdapat korelasi positif yang signifikan antara model pembelajaran Daring dengan pengembangan kreativitas.

Melakukan penilaian melalui nilai pre test post test (pre test post tes ) untuk memperoleh gambaran mengenai efektivitas pembelajaran Mata Pelatihan Berfikir Kreatif yang dilaksanakan secara sistematis melalui konsep metode berpikir kreatif dalam meningkatkan kreatifitas peserta dalam mengidentifikasi isu dan solusi perbaikan kinerja dan pelayanan di unit kerja instansi peserta. Hal tersebut perlu dan penting dilakukan sebagai acuan dalam membuat rencana aksi perubahan peserta PKP kabupaten Bangka Barat.

\section{HASIL DAN PEMBAHASAN}

Untuk mengembangkan kreativitas peserta pelatihan melalui aplikasi zoom meeting. Banyak kendala yang dihadapi oleh para widyaiswara diantaranya terkendala jaringan, waktu yang terbatas untuk tatap muka secara daring dengan peserta, yang biasanya tiada batas waktu dan ruang untuk saling berinteraksi, tanya jawab dan praktek lebih lancar dan mudah di evaluasi. Pandemi covid 19 merubah semua yang biasa terjadi, termasuk para widyaiswaranya harus siap dan menjadi tantangan dengan hambatan-hambatan yang terjadi pada saat pembelajaran Daring. Bagaimana mengembangkan kreativitas dalam menyampaikan pembelajaran kepada para peserta adalah dengan melakukan beberapa metode antara lain: menyusun waktu pembelajaran syncronous yang terdiri dari ceramah, pemutaran video, tanya jawab, chat di WA, diskusi dan paparan hasil diskusi kelompok dan asyncronous yaitu pre test, belajar mandiri, penugasan kelompok mandiri, serta post test.

berdasarkan hasil penelitian ditemukan adanya peserta yang telat masuk zoom, jaringan lemot/error, kurang aktif bertanya, chat respon WA aktif bila diminta. Waktu paparan terbatas dan hanya dilakukan oleh satu orang pemateri dan yang lain pasif, sehingga hanya sedikit yang bertanya dan memberi masukan dari 5 kelompok yang ada dengan 8 peserta perkelompok. Dan berdasarkan penelitian menggunakan metode regresi ditemukan hasil sebagai berikut: 


\section{HASIL BELAJAR}

Nilai Pre dan post tes untuk mata pelatihan Teknik berpikir Kreatif pada peserta PKP menunjukan adanya peningkatan Pengetahuan pada peserta yang baik terdapat rata rata pre tes $(61,94)$ atau $(42,58 \%)$ dan Post tes $(83,53)$ atau $57,42 \%$ terdapat kenaikan sebesar $=21,59$ $(14,84 \%)$

Tabel. 1 Hasil Penilaian Pre test (Y1) dan Post tes (Y2) peserta (X) Pelatihan Kepemimpinan Pengawas Angkatan I

\begin{tabular}{|c|c|c|c|c|c|c|c|}
\hline \multirow[b]{2}{*}{ No. } & \multirow[b]{2}{*}{ Responden } & \multicolumn{2}{|c|}{ Pretest (Y1) } & \multirow{2}{*}{$\begin{array}{l}\text { Total } \\
\text { (Y1) }\end{array}$} & \multicolumn{2}{|c|}{ Post Test (Y2) } & \multirow{2}{*}{$\begin{array}{l}\text { Total } \\
\text { (Y2) }\end{array}$} \\
\hline & & $\begin{array}{l}\text { Essay } \\
\text { (Y1) }\end{array}$ & $\begin{array}{l}\text { Multiple Coise } \\
\text { (Y2) }\end{array}$ & & $\begin{array}{l}\text { Essay } \\
\text { (Y1) }\end{array}$ & $\begin{array}{l}\text { Multiple } \\
\text { Coise(Y2) }\end{array}$ & \\
\hline 1 & $\mathrm{X} 1$ & 43 & 5 & 48 & 50 & 45 & 95 \\
\hline 2 & $\mathrm{X} 2$ & 24 & 30 & 54 & 50 & 45 & 95 \\
\hline 3 & $\mathrm{X} 3$ & 20 & 15 & 35 & 50 & 45 & 95 \\
\hline 4 & $\mathrm{X} 4$ & 29 & 25 & 54 & 50 & 45 & 95 \\
\hline 5 & $\mathrm{X} 5$ & 45 & 10 & 55 & 45 & 45 & 90 \\
\hline 6 & X6 & 43 & 10 & 53 & 45 & 45 & 90 \\
\hline 7 & $\mathrm{X7}$ & 27 & 15 & 42 & 50 & 45 & 95 \\
\hline 8 & $\mathrm{X} 8$ & 27 & 10 & 37 & 25 & 45 & 70 \\
\hline 9 & $\mathrm{X} 9$ & 45 & 20 & 65 & 40 & 45 & 85 \\
\hline 10 & $\mathrm{X} 10$ & 29 & 30 & 59 & 30 & 45 & 75 \\
\hline 11 & $\mathrm{X} 11$ & 20 & 30 & 50 & 35 & 45 & 80 \\
\hline 12 & $\mathrm{X} 12$ & 20 & 20 & 40 & 50 & 45 & 95 \\
\hline 13 & $\mathrm{X} 13$ & 20 & 10 & 30 & 30 & 45 & 75 \\
\hline 14 & $\mathrm{X} 14$ & 20 & 30 & 50 & 40 & 45 & 85 \\
\hline 15 & $\mathrm{X} 15$ & 45 & 25 & 70 & 25 & 38 & 63 \\
\hline 16 & X16 & 28 & 25 & 53 & 50 & 45 & 95 \\
\hline 17 & $\mathrm{X} 17$ & 20 & 20 & 40 & 50 & 45 & 95 \\
\hline 18 & $\mathrm{X} 18$ & 27 & 30 & 57 & 25 & 25 & 50 \\
\hline 19 & X19 & 30 & 30 & 60 & 25 & 45 & 70 \\
\hline 20 & $\mathrm{X} 20$ & 45 & 25 & 70 & 20 & 45 & 65 \\
\hline 21 & $\mathrm{X} 21$ & 45 & 30 & 75 & 50 & 45 & 95 \\
\hline 22 & $\mathrm{X} 22$ & 45 & 40 & 85 & 25 & 45 & 70 \\
\hline 23 & $\mathrm{X} 23$ & 45 & 55 & 100 & 35 & 45 & 80 \\
\hline 24 & $\mathrm{X} 24$ & 45 & 30 & 75 & 45 & 45 & 90 \\
\hline 25 & $\mathrm{X} 25$ & 45 & 25 & 70 & 55 & 45 & 100 \\
\hline 26 & $\mathrm{X} 26$ & 45 & 55 & 100 & 50 & 45 & 95 \\
\hline 27 & X27 & 45 & 50 & 95 & 45 & 45 & 90 \\
\hline 28 & $\mathrm{X} 28$ & 45 & 25 & 70 & 55 & 45 & 100 \\
\hline 29 & X29 & 45 & 35 & 80 & 50 & 45 & 95 \\
\hline 30 & X30 & 0 & 50 & 50 & 35 & 45 & 80 \\
\hline 31 & X31 & 45 & 50 & 95 & 20 & 45 & 65 \\
\hline 32 & X32 & 45 & 20 & 65 & 50 & 45 & 95 \\
\hline 33 & X33 & 0 & 0 & 0 & 50 & 45 & 95 \\
\hline
\end{tabular}


EDUTECH : Jurnal Inovasi Pendidikan Berbantuan Teknologi Vol. 1 No. 2 Agustus 2021, e-ISSN : 2797-0140 | p-ISSN : 2797-0590

\begin{tabular}{|l|l|l|l|l|l|l|l|}
34 & X34 & 0 & 0 & 0 & 30 & 27 & 57 \\
\hline 35 & X35 & 0 & 0 & 0 & 45 & 45 & 90 \\
\hline 36 & X36 & 0 & 0 & 0 & 25 & 45 & 70 \\
\hline 37 & X37 & 0 & 0 & 0 & 45 & 45 & 90 \\
\hline 38 & X38 & 0 & 0 & 0 & 30 & 43 & 73 \\
\hline 39 & X39 & 0 & 0 & 0 & 30 & 43 & 73 \\
\hline 40 & X40 & 0 & 0 & 0 & 55 & 25 & 80 \\
\hline & Jumlah & 1102 & 880 & 1982 & 1610 & 1731 & 3341 \\
\hline & $\begin{array}{l}\text { Nilai Rata- } \\
\text { Rata }\end{array}$ & 34,4375 & 27,5 & 61,9375 & 40,25 & 43,275 & 83,525 \\
\hline
\end{tabular}

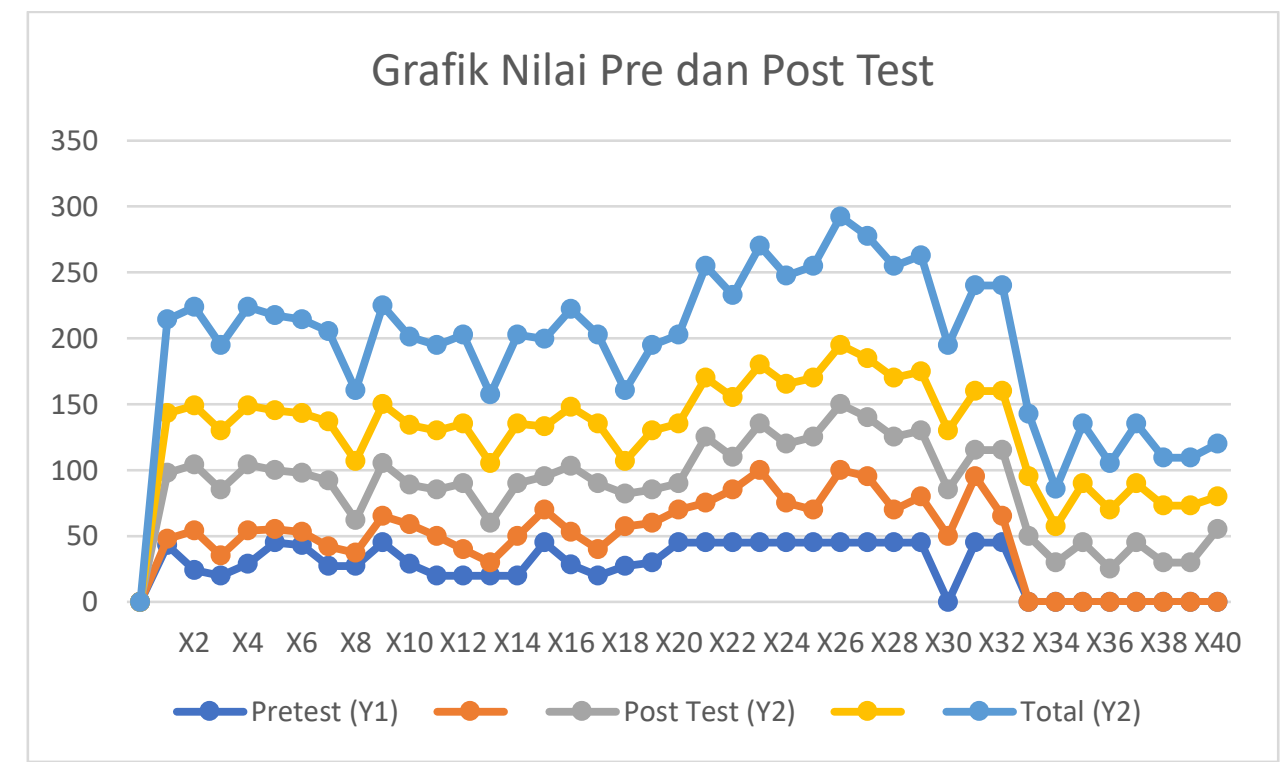

Gambar 2 Grafik Nilai Pre dan Post Test

Pada grafik terdapat perbedaan nilai pre tes dan post tes lebih besar.

Dari hasil uji normalitas didapat hasil Multiple coise sama dengan 1 yaitu dapat dinyatakan uji valitas pertanyaan Normal

Tabel 2 summary $\mathbf{x}$ terhadap y

\begin{tabular}{|l|l|l|l|l|}
\hline Model & R & R.Squere & Adjusted R & $\begin{array}{l}\text { Std.Error of the } \\
\text { Estimate }\end{array}$ \\
\hline 1 & 0.1182 & 0,0139 & -0.0119 & 30.4926 \\
\hline
\end{tabular}

Dari perhitungan pada tabel summary diketahui koefisien korelasi $(r)=0,11898892$ dengan standar error 30,49262978

Untuk menafsirkan angka tersebut digunakan kriteria sebagai berikut :
$0,00-0,25$
Korelasi sangat lemah
$>\quad 0,25-0,50$
Korelasi cukup kuat
$>\quad 0,50-0,75$
Korelasi kuat
$0,75-0,100$
Korelasi sangat kuat

Korelasi $(r)=0,1183$ ini berarti bahwa hubungan antara variabel $\mathrm{X}$ dengan $\mathrm{Y}$ adalah sangat lemah dan searah. Searah maksudnya jika nilai x naik maka nilai y . Untuk mengetahui seberapa 
besar pengaruh variabel $\mathrm{X}$ terhadap $\mathrm{Y}$ digunakan koefisien determinasi (KD) dengan rumus sebagai berikut :

$\left(\mathrm{r}^{2}\right) \quad=$ Koefisien Determinant $(\mathrm{KD})$

$\mathrm{KD}=\mathrm{r}^{2} \times 100 \%$

$\mathrm{KD}=0,0139 \times 100 \%$

$\mathrm{KD}=1,39 \%$

Angka tersebut menunjukkan bahwa Pengaruh $\mathrm{X}$ terhadap $\mathrm{Y}$ sebesar 1,39\% dan sisanya sebesar $98,61 \%$ dipengaruhi variabel lain.

Untuk mengetahui apakah model regresi diatas signifikan maka digunakan Uji F sebagai berikut

Tabel 3 ANOVA untuk persamaan $Y=\mathbf{f}(X)$

\begin{tabular}{|l|l|l|l|l|l|}
\hline Model & $\begin{array}{l}\text { Sum of } \\
\text { sguares }\end{array}$ & df & $\begin{array}{l}\text { Mean } \\
\text { sguaers }\end{array}$ & F & Sig \\
\hline 1. Regrision & 501.4820958 & 1 & 501.4820958 & 0.539344 & 0.46721265 \\
\hline Residual & 35332.4179 & 38 & 929.8004712 & & \\
\hline Total & 35833.9 & 39 & & & \\
\hline & & & & & \\
\hline
\end{tabular}

Hasil Uji F pada Tabel ANOVA dapat disimpulkan bahwa Model 1

$\mathrm{Y}=\alpha+\beta X+\in$ Mendapat nilai $\mathrm{F}=0,539$ signifikan dengan tingkat probabiliti $(\mathrm{p})$ $=0,4672$. Karena sig penelitian 0,4672 >0,05 artinya Ho di terima dan Ha di tolak Untuk bentuk persamaan regresi linier sederhana ( model 1) dapat di lihat pada Tabel dibawah ini :

Tabel 4 Coeficien regresi persamaan $Y=f(X)$

\begin{tabular}{|l|c|c|l|l|l|}
\hline Model & \multicolumn{2}{|l|}{ Unstandardized coefficients } & $\begin{array}{l}\text { Standardiz } \\
\text { ed } \\
\text { coefficient } \\
\text { s }\end{array}$ & T & Sig \\
\hline & $\beta$ & Std. Error & $\beta$ & & \\
\hline Intercept & 26.5159369 & 31.73285239 & $\begin{array}{l}0.8355989 \\
11\end{array}$ & & 0.408604 \\
\hline $\begin{array}{l}\text { Multiple Coise } \\
\text { (X1) }\end{array}$ & 0.275774476 & 0.375509763 & $\begin{array}{l}0.7344002 \\
82\end{array}$ & & 0.467213 \\
\hline & & & & & \\
\hline
\end{tabular}

Persamaan regresinya $=\mathrm{Y}=26,51+0,275+30.4926$

Dengan persamaan regresi terbentuk $y=26.5159+(0,2757 \mathrm{X})$ artinya dengan kenaikan

a. Variabel X memberikan nilai sebesar 26.5159 yang berarti bahwa variabel bebas tersebut mempunyai arah koefisien yang bertanda positif terhadap kreatifitas Peserta PKP

b. Koefisien X memberikan nilai 0,2757 yang berarti bahwa jika nilai $X$ semakin tinggi, dengan asumsi variabel lain tetap maka kreativitas akan mengalami peningkatan satu kali sebesar 0,2757

Pengujian pegaruh variabel bebas terhadap variabel terikat dilakukan dengan menggunakan uji $\mathrm{F}$. Hasil perhitungan statistik menunjukakan nilai $\mathrm{F}$ hitung $=0,539$ dan $\mathrm{F}$ tabel dengan df $1 ; 38$ pada $\alpha(0,05)$ sebesar (uji 2 sisi) dengan df $=n-k-1$ atau $40-2-1=37$ sehingga diperoleh $\mathrm{T}$ table 0.734 dengan demikian artinya bahwa $\mathrm{F}$ hitung $(0,539)>\mathrm{F}$ Tabel $(0.734)$ dan nilai signifikan sebesar 0.467. Degan menggunakan batas signifikasi 0, 05, maka diperoleh nilai signifikan tersebut lebih besar dari 0,05 sehingga jelas Ho diterima dan $\mathrm{H} 1$ ditolak. Hal ini 
menunjukan bahwa variabel bebas mempunyai tidak berpengaruh terhadap kreativitas peserta PKP Kabupaten Bangka Barat. Pengujian dilakukan dengan melihat taraf signifikan ( $\mathrm{p}-$ value), jika taraf signifikan yang dihasilkan perhitungan dibawah 0,05 maka diterima, sebaliknya jika taraf signifikan hasil hitung lebih besar dari 0,05 maka hipotesis ditolak.

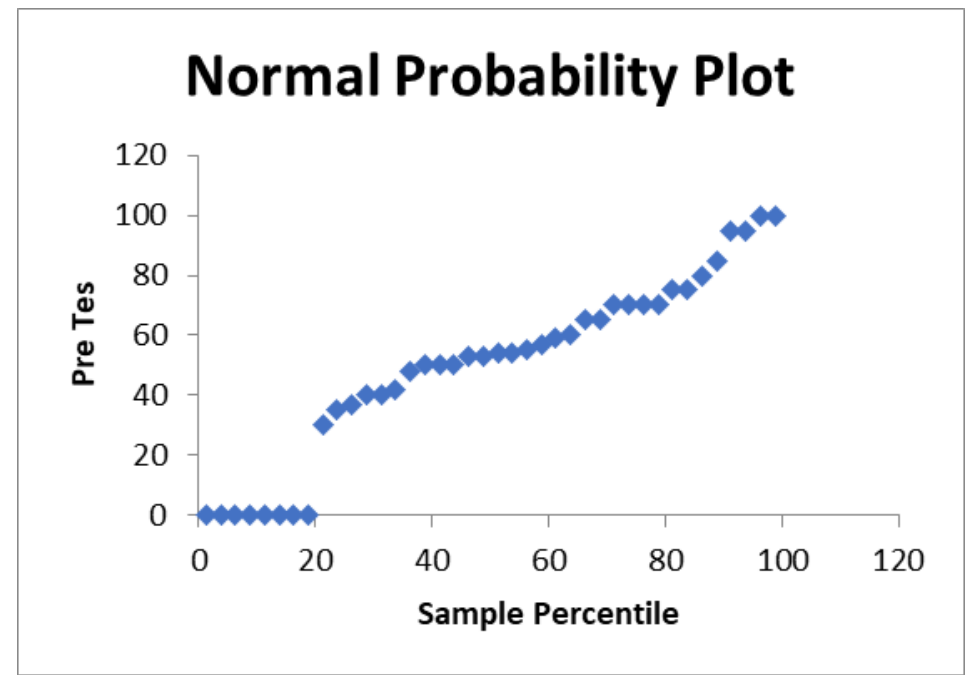

Gambar 3. Grafik Normal Probability Plot

Data hasil pengujian dengan grafik plot pada chat tersebut menunjukkan terdapat corelasi yang kuat antara essay dengan sample percentile, sehingga memenuhi persyaratan normalitas. Pada gambar terlihat data yang membentuk garis mendatar di sekitar angka 0 ( 0 pada sumbu Y), dan tidak membentuk garis tertentu. Dengan demikian, data memenuhi persyaratan untuk analisis regresi.

\section{KREATIVITAS}

Kreativitas Aksi perubahan Peserta PKP terhadap 5 orang peserta dari 40 peserta seluruhnya yang diteliti terdapat beberapa kreativitas antara lain terdapat 5 judul aksi perubahan yang berbeda dari masing-masing peserta.Tiga dari peserta berasal dari kantor Dinas yang sama 2 peserta dan satu peserta dari unit kerja ditingkat kecamatan yang berhubungan, sedangkan dua peserta lainnya dari kantor dinas yang berbeda dalam wilayah kabupaten. Berdasarkan Laporan Aksi Perubahan Kinerja Pelayanan Publik yaitu : dengan judul aksi perubahan sebagai berikut:

1. OPTIMALISASI PEMBINAAN BERBASIS WEB PROGRAM INDONESIA SEHAT DENGAN PENDEKATAN KELUARGA (PIS-PK) TERHADAP PUSKESMAS SEKABUPATEN BANGKA BARAT OLEH DINAS KESEHATAN KABUPATEN BANGKA BARAT MELALUI TIM TERPADU

2. AKSELERASI KERJASAMA BUMDESA PADA PROGRAM SEMBAKO MELALUI "KLINIK KERJASAMA BUMDESA"

3. SISTEM PENGUMPULAN LAPORAN STANDAR PELAYANAN MINIMAL (SPM) BERBASIS APLIKASI DI PUSKESMAS TEMPILANG

4. PENGELOLAAN DOKKUMEN KEPEGAWAIAN YANG EFEKTIF DAN EFISIEN MELALUI PENYIMPANAN DOKUMEN ADMINISTRASI KEPEGAWAIN SECARA ELEKTRONIK

5. SISTEM INFORMASI GEOGRAFIS FASILITAS KESEHATAN PUSKESMAS KABUPATEN BANGKA BARAT BERBASIS APLIKASI GOOGLE MAPS

Lebih lanjut digambarkan bahwa ke lima aksi perubahan tersebut telah berhasil diimplentasikan dan peserta telah dinyatakan lulus setelah melalui evaluasi seminar rancangan dan seminar laporan aksi perubahan. Dari hasil rekapitulasi laporan kelima aksi perubahan telah berhasil mengatasi permasalahan pada unit kerja bidang tugas peserta masing- masing sehingga 
aksi perubahan ini telah dapat mewujiudkan visi dan misi organisasi dan meningkatkan kinerja organisasi.

Tabel 5. Jenis kelamin, tingkat pendidikan dan kehadiran peserta

\begin{tabular}{|l|l|l|l|}
\hline Uraian/komponen & $\begin{array}{l}\text { Jenis } \\
\text { Kelamin }\end{array}$ & Pendidkan & Telat Hadir \\
\hline Laki-laki & $16(40 \%)$ & & \\
\hline perempuan & $24(60 \%)$ & & \\
\hline DIII & & $9(22,5 \%)$ & \\
\hline SI & & $30(75 \%)$ & \\
\hline S2 & & $1(2,5 \%)$ & \\
\hline Pre test & & & $4(10 \%)$ \\
\hline Post test & & & $1(2,5 \%)$ \\
\hline Paparan & & & $1(2,5 \%)$ \\
\hline Tepat waktu hadir & & $34(85 \%)$ \\
\hline
\end{tabular}

Sumber ; Data dioleh Penelti

Dari Tabel 5 diatas dapat disimpulkan bahwa terdapat peserta terbanyak Perempuan $60 \%$ dan Laki-laki 40\%, Pendidikan peserta terbanyak S1 (75\%), DIII $(22,5 \%)$ dan S2 (2,5\%), dan telat hadir terbanyak pada saat pre test $(10 \%)$ dan saat paparan materi dan postes masing masing $(2,5 \%)$ serta tingkat kehadiran tepat waktu $85 \%$ dan $15 \%$ tidak tepat waktu. Hal ini disebabkan kendala Jaringan internet yang belum stabil.

Bersadarkan penelitian sebelumnya, Menurut Kumaat (2016), Kemajuan teknologi yang semakin canggih serta munculnya organisasi-organisasi baru menjadikan persaingan semakin mengglobal. Persaingan tersebut membuat organisasi termasuk instansi pemerintahan berpikir bagaimana cara untuk dapat bertahan dalam kondisi lingkungan yang berubah. Suksesnya suatu organisasi ditentukan oleh kemampuan organisasi untuk beradaptasi pada perubahan lingkungan dan berbagai faktor yang mempengaruhi kinerja organisasi tersebut seperti faktor Pendidikan, Pelatihan dan Inovasi. Penelitian ini untuk mengetahui pengaruh Pendidikan, Pelatihan, dan Inovasi terhadap Kinerja Pegawai baik secara simultan maupun parsial. Populasi dalam penelitian ini sebanyak 59 orang dengan teknik sampling jenuh sehingga semua anggota populasi diambil sebagai responden. Metode penelitian menggunakan assosiatif dengan teknik analisis Regresi Berganda. Hasil penelitian menunjukkan Pendidikan, Pelatihan, dan Inovasi memiliki pengaruh yang positif dan signifikan terhadap Kinerja Pegawai pada Badan Pelaksana Penyuluhan dan Ketahanan Pangan Kota Manado (BPPKP) baik secara simultan maupun parsial. Hal ini sejalan dengan penelitian ini dimana pertama : Variabel X memberikan nilai sebesar 26.5159 yang berarti bahwa variabel bebas tersebut mempunyai arah koefisien yang bertanda positif terhadap kreatifitas Peserta PKP. Kedua : Koefisien X memberikan nilai 0,2757 yang berarti bahwa jika nilai $X$ semakin tinggi, dengan asumsi variabel lain tetap maka kreativitas akan mengalami peningkatan satu kali sebesar 0,2757.

Sedangkan menurut Masambe (2015), Era globalisasi saat ini menuntut kinerja organisasi yang tinggi untuk dapat bertahan hidup ditengah-tengah tingkat persaingan yang sangat ketat. Penelitian ini untuk mengetahui faktor-faktor yang mempengaruhi kinerja karyawan dilihat dari gaya kepemimpinan, budaya organisasi dan inovasi pemimpin. Metode Analisis yang digunakan adalah analisis regresi berganda.Populasi penelitian berjumlah 37 karyawan dan sampel berjumlah 37 responden. Hasil penelitian menunjukkan gaya kepemimpinan, budaya organisasi dan inovasi pemimpin berpengaruh secara simultan. Secara parsial pengaruh gaya kepemimpinan dan inovasi pemimpin berpengaruh baik dan positif terhadap kinerja karyawan Daihatsu Kharisma Manado. Dari hasil uji t pada tabel diatas dapat dilihat bahwa signifikansi $\mathrm{p}$-value $=0,025<0,05$, maka dapat disimpulkan bahwa Ha diterima dan menolak H0 atau Inovasi (X1) berpengaruh signifikan terhadap Kinerja Karyawan(Y). Dari hasil uji t pada tabel diatas dapat dilihat bahwa Kreatifitas (X2) signifikansi p-value $=0,002<$ 
0,05, maka dapat disimpulkan bahwa Ha diterima dan menolak H0 atau Kreatifitas (X2) berpengaruh signifikan terhadap Kinerja Karyawan(Y). Hal ini tidak sejalan dengan hasil penelitian ini dimana terdapat nilai $F=0,539$ signifikan dengan tingkat probabiliti $(p)=0,4672$. Karena sig penelitian 0,4672 >0,05 artinya Ho di terima dan Ha di tolak Dari kesimpulan data tersebut diatas dan pendapat dari hasil penelitian sebelumnya dapat dinyatakan penelitian ini sejalan dengan penelitian yang dilakukan oleh Kumaat, bahwa kemajuan teknologi dapat mempengaruhi keberhasilan organisasi dalam meningkatkan kinerja dan kreativitas pegawai. Dan juga sejalan dengan penelitian yang dilakukan oleh Mesase, bahwa organisasi harus berkinerja tinggi dalam persaingan yang ketat di era globalisasi maka inovasi pemimpin sangat penting dan berpengaruh signifikan terhadap kinerja pegawai untuk melakukan pengembangan kreativitas dan inovasi dalam mewujudkan pencapaian tujuan oranisasi.

\section{KESIMPULAN}

Dari hasil penelitian dan pembahasan di atas, adalah sebagai berikut :

1. Hasil belajar secara simultan berpengaruh signifikan terhadap Kreativitas peserta

2. Hasil Belajar secara parsial berpengaruh signifikan terhadap Kreativitas peserta

3. Kreativitas secara parsial berpengaruh signifikan terhadap Kinerja peserta

\section{DAFTAR PUSTAKA}

Dama1, J , Ogi2, J. (2018). Pengaruh Inovasi Terhadap Dan Kreativitas Terhadap Kinerja Karyawan Pada Pt Bank Mandiri (Persero) Tbk. Manado.

Handayani, L. (2020). "Peningkatan Motivasi Belajar IPA Melalui Model Pembelajaran Project Based Learning pada Masa Pandemi Covid-19 bagi Siswa SMP Negeri 4 Gunungsari Kabupaten Lombok Barat.Jawa Barat.

Kunia D. (2021). Konseling Spiritual Teistik Untuk Meningkatkan Kedisiplinan Siswa Mts Negeri 3 Bandung Jawa Barat. Bandung Jawa Barat.

Wahyudi D dan Adila U. Pengabdian Masyarakat Dari Rumah Di Tengah Pandemi Covid-19. CV. Creative Tugu Pena. Lampung. 